\title{
Turkey's Energy Strategy for 2023 Targets after 2000 MW Giant Renewable Energy Contract
}

\author{
Haci Sogukpinar ${ }^{1}$, Ismail Bozkurt ${ }^{2}$, and Serkan $\mathrm{Cag}^{3}$ \\ ${ }^{1}$ Department of Electric and Energy, Vocational School, University of Adiyaman, Adiyaman 02040, Turkey \\ ${ }^{2}$ Department of Mechanical Engineering, Faculty of Engineering, University of Adiyaman Adiyaman 02040, Turkey \\ ${ }^{3}$ Department of Machinery and Metal Technology, Vocational School, University of Adiyaman, Adiyaman 02040, Turkey
}

\begin{abstract}
Turkey wants to become the world's 10th largest economy in the 100th anniversary of the foundation of the republic of Turkey. In order to achieve this goal, there are many breakthroughs in the political, economic and in energy fields. Turkey's installed power capacity was $85000 \mathrm{MW}$ in 2017 but installed power of $125.000 \mathrm{MW}$ is targeted to achieve the objective of 2023 targets. The government is aiming to increase the total production of renewable energy share by $30 \%$ in 2023 , while foreseeing the increase in capacity due to nuclear and fossil fuel consumption. Targets for different technologies are 34000 MW hydroelectric, $20000 \mathrm{MW}$ wind energy, $5000 \mathrm{MW}$ solar energy (photovoltaic and condensed solar energy), $1000 \mathrm{MW}$ geothermal energy and $1000 \mathrm{MW}$ biomass. Capacity utilization in hydroelectricity is $62 \%$, wind power is $14 \%$, and geothermal power is $33 \%$. The total installed capacity of Biogas, Biomass, Waste Heat and Pyrolytic Oil Power Plants is $530 \mathrm{MW}$. Theoretical total power capacity of the solar energy for Turkey as $300 \mathrm{TWh} /$ year and reached $45 \%$ of the 2023 target in 2017 in the last three years. However, it is estimated that the targets of 2023 in solar energy can be exceeded. Government offers attractive incentive packages for renewable and other energy sector to achieve 2023 goals. In order to encourage domestic production, a total of $2000 \mathrm{MW}$ wind and solar energy installation bid was carried out in 2017. This contract is expected to make Turkey as energy hub both in terms of installation and technology. In this study, Turkey's renewable energy potential, and energy strategies and breakthroughs for this were investigated and discussed.
\end{abstract}

\section{Introduction}

Turkey has world's 17th and Europe's 6th largest economy and wants to have the world's 10th largest economy in 2023. Turkey Statistical Institute (TSI), announced its 2017 economic growth data for Turkey and Turkey's economy recorded 7.4 percent growth in 2017 [1]. Therefore Turkey is experiencing a sharp increase in demand for energy. $55 \%$ of the total electricity production was provided from imported natural gas and coal in 2017. When considering heating in the houses and transportation costs, Turkey's dependence on foreign energy is about 70 percent [2]. It is inevitable to encourage the use of domestic and renewable energy sources under the assumption that this rate may increase in the future. On the one hand Turkey wants to meet at least 30 percent of the total electricity demand from renewable energy 2023. Considering electric vehicles will be a certain rate in the next decade, the transportation sector aims to meet $10 \%$ of energy demand from renewable energy [3]. Turkey, with regard to minimizing the negative environmental impact of industrial activity, became a member to the United
Nations Framework Convention on Climate Change and has ratified the Kyoto Protocol on 28 May 2009[4]. Therefore Turkey has been implementing a series of measures against adverse environmental impacts since 2010. With the new incentive legislation, investments in the wind energy sector accelerated in 2006. Total installation was 20MW until 2005, but only in 2006 $30 \mathrm{MW}$ was installed and installation capacity has increased very rapidly each fallowing year [5]. Total installation passed $3000 \mathrm{MW}$ at the end of 2013 and approached $7000 \mathrm{MW}$ in 2018. Turkey installed more than $2000 \mathrm{MW}$ of new wind power capacity during 2016 and 2017[6]. Considering the 2023 targets, $35 \%$ of it has already been achieved and there is still much work to be done. However, the government made a $1000 \mathrm{MW}$ installment bid in 2017 to speed up investments. Renewable energy (including hydropower) now accounts for $28.73 \%$ of Turkey's total installed power generation capacity. It is estimated that the consumption of electricity in 2023 will increase about twice compared to today and the share of renewable energy in electricity generation is aimed to be at least 30 percent [7]. European countries installed 15,680 MW of new wind power capacity during 2017 and Germany installed 42\% 
of the total EU new installation [8]. The share of renewable energy in the EU's total installed power capacity has increased from $26 \%$ in 2005 to $47 \%$ in 2017 . Turkey is a candidate country to the European Union even if membership did not occur but the clean energy strategy of Europe has set the objective of turkey and is also working on the development of local technology. Turkey is trying to increase the appeal by introducing new incentive laws in order to increase the share of solar energy in electricity generation. Turkey's average annual sunshine duration is 2640 hours, which equals a total of 7.2 hours per day. The average annual total solar radiation is $1311 \mathrm{kWh} / \mathrm{m}^{2}$ this equals to the daily total of $3.6 \mathrm{kWh} / \mathrm{m}^{2}$.

The total installation was around $50 \mathrm{MW}$ at the beginning of 2015, whereas in 2016 the installation was reached $442 \mathrm{MW}$ [9] and passed $2250 \mathrm{MW}$ at the end of 2017. Considering Turkey's solar potential, installation is not yet at the desired level but the government tries to accelerate the total installed power by making a bid for installation of $1000 \mathrm{MW}$ in 2017. There are indigenous design and production technologies in the specifications of the tender for both solar and wind power installation. Of course, we should not only think about electricity generation, because energy is consumed quite high in order to meet our daily need for hot water. Roof type collectors have used widely in the last 40 years and studies on solar ponds have been continuing [10,11]. On the other hand Turkey is using $62 \%$ of the total capacity of hydroelectric power and the total installed capacity of 597 Plants in Turkey is 26,694.92 MW. Some of the remaining part is in the phase of installation and some of it is in the phase of licensing and project and when they are all completed total power will be 43,682 MW.

The Turkish government has issued two bid announcements with the aim of increasing installation and developing domestic technology. The winning companies will be able to set up a $1000 \mathrm{MW}$ solar and $1000 \mathrm{MW}$ wind power plant if they meet the requirements. In this study Turkey's renewable energy potential was investigated and 2023 goals were discussed and the effects of these two bid on 2023 targets were examined.

\section{Wind power}

Turkey is quite in a good condition in terms of wind energy potential. Total commercial wind power potential of Turkey is around 48,000 MW. Figure 1 shows that the offshore wind energy potential is concentrated in the Aegean and Marmara sea and onshore wind energy potential is extended along the coast of the Aegean sea to Marmara region. Other wind energy potential is concentrated around Hatay in Mediterranean Sea and around Sinop in Black sea region. In inner regions where highly elevated areas are usually complex terrains. The wind energy potential in the inner part are local winds originating from the mountainous structure especially in eastern Anatolia region. Turkey's wind potential is given in Table 1 . The wind speed value more than $4 \mathrm{~m} / \mathrm{s}$ is of particular interest since it is typically only at wind speeds above this threshold that turbines can operate effectively [12]. Turkey's wind energy potential between $7 \mathrm{~m} / \mathrm{s}$ and $7,5 \mathrm{~m} / \mathrm{s}$ is about $30,000 \mathrm{MW}$, and for $7.5 \mathrm{~m} / \mathrm{s}$ and higher speed is around 18.000 MW. Electricity has been generated from a total of 6752 MW (14\% of total potential in 2017 and $33 \%$ of 2023 target) and wind power plants under construction is $552 \mathrm{MW}$ and wind power plants under the licensed and under project phase is $1500 \mathrm{MW}$. Considering that all of them including the project phase is completed, a $9000 \mathrm{MW}$ wind power plant will have been established, which means that nearly half of the target will be realized. The government made a serious attempt to achieve these goals in 2017. Ministry of Energy and Natural Resources announced 1000 MW Wind Energy bid announcement. The main purpose here is to speed up the installation process while also ensuring the development of domestic production technology. On August 3, 2017, the German-Turkish consortium of Siemens-Türkerler-Kalyon offered the lowest bid at $0.0348 \mathrm{US} \$$ per $\mathrm{kWh}$ for the delivery of electricity to the national grid. The factory to produce domestic wind turbines will have a production capacity of at least 150 units/year or $400 \mathrm{MW} /$ year wind turbine. With the power plant going into operation, a minimum of 3 billion $\mathrm{kWh}$ of electricity will be generated each year and about 1.1 million homes will be covered by the annual electricity demand. The consortium will carry out R\&D work, for ten years, on wind turbine blades, generator design, materials technology and production techniques, software and innovative gearbox areas. R\&D activities will be carried out with 50 technical personnel consisting of $80 \%$ domestic engineers, while budget of $\$ 5$ million is allocated for R \& D work every year. The installation period of the industry will be 21 months from the date of contract signing, and the license will last 30 years. With this and similar incentives, It is aimed development of the Turkish industry and the goals of taking part in the top 10 economies in 2023.

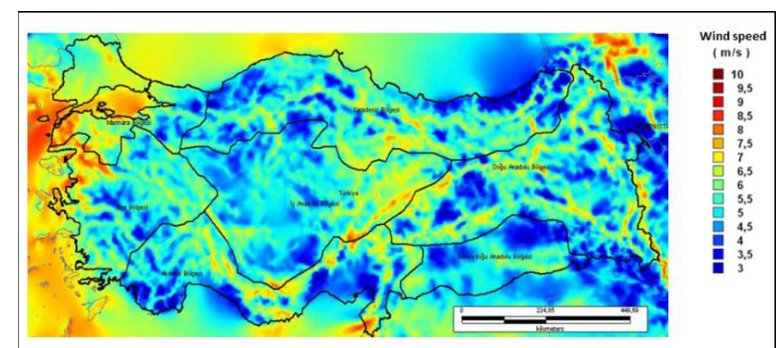

Fig. 1. Turkey wind map $[13,14]$.

Table 1. Wind power potential vs. wind speed distribution [15]

\begin{tabular}{clc}
\hline $\begin{array}{c}\text { The average annual } \\
\text { wind speed }(\mathbf{m} / \mathbf{s})\end{array}$ & $\begin{array}{c}\text { Power density } \\
\left(\mathbf{W} / \mathbf{m}^{2}\right)\end{array}$ & Capacity $(\mathbf{M W})$ \\
\hline $7.0-7.5$ & $400-500$ & $29,259.36$ \\
$7.5-8.0$ & $500-600$ & $12,994.32$ \\
$8.0-9.0$ & $600-800$ & $5,399.92$ \\
$>9.0$ & $>800$ & 195.84 \\
& Total & $47,849.00$ \\
& $\begin{array}{l}\text { Onshore } \\
\text { (MW) }\end{array}$ & $37,836.00$ \\
& Offshore(MW) & $10,013.00$ \\
\hline
\end{tabular}




\section{Solar power}

Turkey has high solar energy potential due to its geographical location compared to many other European countries. Turkey's average annual sunshine duration were measured 2640 hours (a total of 7.2 hours per day), and the average total solar radiation was calculated as $1311 \mathrm{kWh} / \mathrm{m}^{-2}$ year (daily total of $3.6 \mathrm{kWh} / \mathrm{m}^{2}$ [9]) Turkey's solar map is given in the Figure 2 and average solar radiation and total sunshine durations is given in Table 2. East and south-east Anatolia region are two of the most solar potential of Turkey but the other five regions are in a quite good condition when compared to European countries [16]. The state provides a purchase guarantee for a 1-kWh electric energy generated from unlicensed solar power plants for a 10-year period of $\$ 13.3$ cents and agreements are renewed every 10 years. The solar and wind energy systems to be built for houses in turkey have cost recovery times ranging from about 6 to 10 years $[17,18]$.

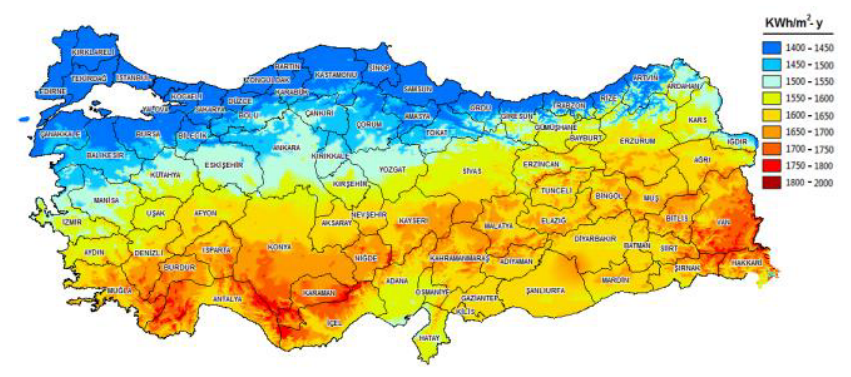

Fig. 2. Turkey's solar map[19].

Table 2. Average solar radiation and total sunshine durations

\begin{tabular}{|l|c|c|}
\hline Region & $\begin{array}{c}\text { Total Solar } \\
\text { radiation } \\
\text { Energy(kWh/m2- } \\
\text { year) }\end{array}$ & $\begin{array}{c}\text { Sunshine } \\
\text { duration( } \\
\text { h/year) }\end{array}$ \\
\hline South East Anatolia & 1460 & 2993 \\
\hline Mediterranean & 1390 & 2956 \\
\hline Eastern Anatolia & 1365 & 2664 \\
\hline Central Anatolia & 1314 & 2628 \\
\hline Aegean & 1304 & 2738 \\
\hline Marmara & 1168 & 2409 \\
\hline Black sea & 1120 & 1971 \\
\hline
\end{tabular}

There is no storage system, so the amortization time for solar power plant is around 6 years. Investments related to solar energy have gained momentum by 2016 and the total installed volume has risen to $2250 \mathrm{MW}$ in 23 years. The state has implemented the $1000 \mathrm{MW}$ Karapinar Renewable Energy Resource Area power plant Karapinar bid to accelerate the installation and to improve the technological infrastructure in the Ministry of Energy and Natural Resources with the participation of 4 consorsium. Turkish Kalyon with South Korean partner Hanwha Group offered the lowest bid at 0.0699 US\$ per $\mathrm{kWh}$ for the delivery of electricity to the national grid. The under the scope of the agreement, a factory to be constructed with a production capacity of
500 megawatts of photovoltaic modules. The consortium will carry out R\&D work, for ten years, on module design and increasing cell efficiency. The goal is to have 60 percent of the domestic technology rate in the first $500 \mathrm{MW}$ and 70 percent in the second 500 megawatt. The factory will be established in 21 months following the signing of the contract and the photovoltaic modules to be produced at the plant will be installed in the field. The project aims to increase the production of electricity from renewable source and also equipment to make technology transfers and to reduce the dependency on foreign companies in the coming years. Karapinar will be Turkey's largest solar power plant, which will be the first application based on the condition of indigenization in the energy sector and on the basis of price determination based on renewable energy sources. While 1.3 billion dollars investment is expected with the project, 1.7 billion kilowatt electricity will be generated from the plant and 600,000 house needs will be met. Solar cell production in Turkey are not yet in the commercial sense, but is made for R \& D. Besides this, 18 companies have been producing solar module with good standards but after the $1000 \mathrm{MW}$ bid, other domestic and foreign companies have begun licensing work for domestic cell production. It is estimated that the inner Anatolia region will be the solar technology center in the next 10 years.

\section{Geothermal and biomass}

Turkey's theoretical geothermal potential is given in the Figure 3 and total potential is 31,500 MW, and 78\% of potential is in western Anatolia, 9\% in Central Anatolia, 7\% Marmara Region, 5\% in Eastern Anatolia 1\% are located in other regions. $90 \%$ of geothermal resources are low and medium temperature and suitable for direct applications (heating, thermal tourism, mineral waters etc.) and $10 \%$ for indirect applications (electric energy production) [20].

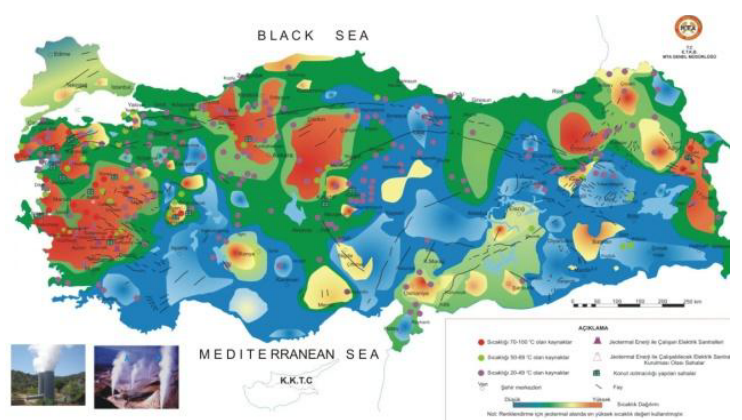

Fig. 3. Turkey's geothermal map [21].

There are 39 Geothermal Power Plants in Turkey with total installed capacity of 1,028 MW and 1,98\% of the electricity is produced from geothermal power plants in 2017 [21]. The first five countries for geothermal energy usage (for non-electrical) for direct geothermal applications are China, the USA, Sweden, Turkey and Iceland. Theoretical total power capacity of the solar energy for Turkey was calculated $300 \mathrm{TWh} /$ year [22]. The total installed capacity of 82 Biogas, Biomass, Waste Heat and Pyrolytic Oil Power Plants is $530 \mathrm{MW}$ and 
$1.27 \%$ of the electricity is produced from these power plants in 2017.

\section{Conclusion}

Turkey generated $29,09 \%$ of the electricity from renewable energy sources in 2017 and want to increase from 85,000 MW (2017) to $125.000 \mathrm{MW}$ in 2023 with $30 \%$ of renewable energy. In order to increase the use of clean energy resources, $20000 \mathrm{MW}$ for wind power and 5000 MW for solar power have been targeted for the 100th anniversary of republic of Turkey. In addition to this, Turkey is planning to rise among the world's top 10 economies in 2023. In order to achieve these goals, serious work is being done in areas such as the development of advanced technology, the design and production of high value added products and the reduction of external dependency on energy. Energy is a common problem in all countries of the world and it is important to meet the needs with local resources. However, global warming, which has been on the agenda for the past 30 years, has now ceased to be effective in everyday life and greenhouse gas reduction measures need to be taken. On the other hand, it is necessary to meet the increasing energy demand every year. Although hydropower has reached a certain saturation in the world but there is enough potential for wind and solar energy. Turkey to meet the growing need for energy on one hand making a serious investment on nuclear power plants, the fossil-fueled power plants and renewable energy sources, on the other hand offers attractive incentives to the private sector. Only $14 \%$ of the electricity was generated by state-owned power plants, while the remaining $86 \%$ was produced directly or indirectly by the private sector in the last year.

\section{References}

1. Turkish Statistical Institute, "Periodic Gross Domestic Product", Ankara, Turkey, available at:http://www.tuik.gov.tr.

2. E.T. Karagöl, I. Kavaz, "Dünyada Ve Türkiye'de Yenilenebilir Enerji”, Volume: 19, April 2017

3. Ministry of Energy and Natural Resources General Directorate of Renewable Energy, "Turkish National Renewable Energy Action Plan", Ankara, 2014

4. Republic of Turkey Ministry of Foreign Affairs, "Kyoto Protocol", Ankara,Turkey, 2017

5. H. Sogukpinar, I. Bozkurt,'Wind energy utilization, potential and targets after 2013 in Turkey, Europe and the world", Adıyaman Üniversitesi Mühendislik Bilimleri Dergisi, vol. 1 (3), (2014), pp. 23-33.

6. TWEA (Turkish Wind Energy Association), (2017). "Türkiye Rüzgâr Enerjisi İstatistik Raporu". Available at:http://www.tureb.com.tr TUREB, 2017.

7. H. Sogukpinar, I. Bozkurt., S. Cag, "Economic Wind Potential and Effect of Feed in Tariff on Installation in Turkey", 2016 IEEE International Conference on Power and Renewable Energy,2016, pp 649-652.
8. Wind in power 2017, "Annual combined onshore and offshore wind energy statistics", February 2018.

9. H. Sogukpinar, I. Bozkurt., S. Cag, "Experimental and Numerical Analysis of Solar Potential and Feed in Tariff in Turkey", 2016 IEEE International Conference on Power and Renewable Energy, 2016, pp 594-597.

10. H. Sogukpinar, I. Bozkurt., S. Cag, "Numerical Evaluation of the Performance Increase for a Solar Pond With Glazed and Unglazed", 2016 IEEE International Conference on Power and Renewable Energy,2016, pp. 594-597.

11. H. Sogukpinar, I. Bozkurt, M. Karakilcik, "Performance Comparison of Aboveground and Underground Solar ponds", Thermal Science, Volume 22,2018, pp. 1-9

12. Europe's onshore and offshore wind energy potential, "An assessment of environmental and economic constraints", EEA Technical report No 6/2009.

13. EIE-Yenilenebilir Enerji genel Müdürlüğü, "Türkiye Rüzgâr Enerjisi Potansiyeli; 2015”. Available at: $<$ http:// www.eie.gov.tr//>

14. H. Sogukpinar, I. Bozkurt., "Adiyaman wind potential and statistical analysis, in Turkey",AIP Conference Proceedings 1815, 040006 (2017); doi: 10.1063/1.4976375

15. H. Sogukpinar, I. Bozkurt, M. F. Baran, H. Turkmenler, M. Pala, K.E. Engin, A.I. Kaya, "Micro-Turbine Design, Production and Testing", International Journal of Engineering Technologies Vol.1, No.4, 2015.pp. 141-145

16. H. Sogukpinar, I. Bozkurt., N. Calis, "A Comparison of Experimental and Estimated Data Analyses of Solar Radiation, in Adiyaman, Turkey", International Journal Of Engineering Technologies Vol.1, No.3, 2015,pp.113-117

17. H. Sogukpinar, I. Bozkurt, "Analysis on Meeting the Electric Energy Demand with Small Wind Turbine in Turkey", International Journal Of Engineering Technologies ,Vol.1, No.2, 2015,pp.51-55

18. H. Sogukpinar, I. Bozkurt, An Economic Analysis Of Residential Pv System For Adiyaman, Turkey, Uludağ University Journal of The Faculty of Engineering, Volume 20, Number 2, 2015,pp.111118

19. Meteorology Regional Offices Turkish State Meteorological Service. "Turkey's solar map", Ankara, Turkey. https://www.mgm.gov.tr/ .[accessed 10 March 2018].

20. Ministry of Energy and Natural Resources, ankara,Turkey. Available at http://www.enerji.gov.tr/tr-TR/Sayfalar/Biyokutle.

21. The Foundation of the People Caring For The Future http://www.carfu.org/

22. H. Olgun, "Status Of Bioenergy In Turkey", Workshop on International cooperation in the field of bioenergy, 22-24 October, Moscow, Russia. 